Provided for non-commercial research and education use. Not for reproduction, distribution or commercial use.

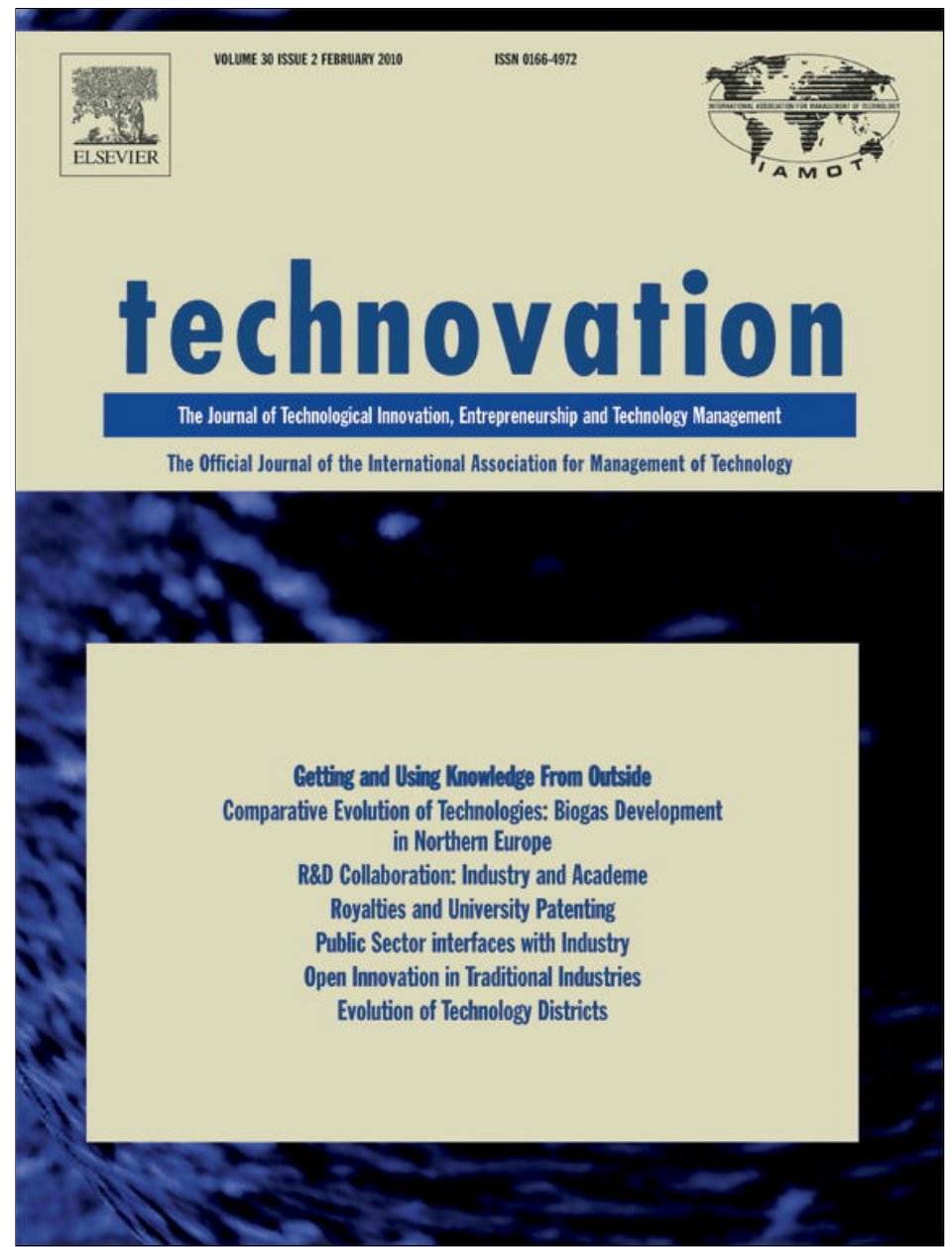

This article appeared in a journal published by Elsevier. The attached copy is furnished to the author for internal non-commercial research and education use, including for instruction at the authors institution and sharing with colleagues.

Other uses, including reproduction and distribution, or selling or licensing copies, or posting to personal, institutional or third party websites are prohibited.

In most cases authors are permitted to post their version of the article (e.g. in Word or Tex form) to their personal website or institutional repository. Authors requiring further information regarding Elsevier's archiving and manuscript policies are encouraged to visit:

http://www.elsevier.com/copyright 


\title{
Socio-cognitive evolution in niche development: Comparative analysis of biogas development in Denmark and the Netherlands (1973-2004)
}

\author{
R.P.J.M. Raven *, F.W. Geels \\ Eindhoven University of Technology, IPO 2.10, P.O. Box 513, 5600 MB Eindhoven, The Netherlands
}

\section{A R T I C L E I N F O}

\section{Keywords:}

Socio-cognitive evolution

Technological niche development

Biogas

Comparative analysis

Sustainability

\begin{abstract}
A B S T R A C T
This article addresses the topic of radical innovation, making two additions to the strategic niche management (SNM) approach, which conceptualises how innovations cross the 'valley of death'. First, it articulates the theoretical foundations of SNM, theorizing the connections between social constructivist and evolutionary theories of technical change. Second, the resulting socio-cognitive evolution perspective is used to explain the different patterns in biogas development in the Netherlands and Denmark. In both countries, biogas experienced ups and downs, but the timing and shape of developments differ. A longitudinal, comparative case analysis shows that the socio-cognitive evolution perspective is useful in explaining these differences.
\end{abstract}

(c) 2009 Elsevier Ltd. All rights reserved.

\section{Introduction}

This article adds to the debate about radical innovation, focusing in particular on the so-called 'valley of death', which refers to the gap between research and market introduction that many radical innovations fail or take a long time to cross. It is well known that the period between invention and innovation (viable market introduction) is often about two or three decades (Table 1).

The literature has identified several reasons for the "valley of death' and the time lag for crossing it. First, new technologies may initially have low performance, which reduces market viability. Mokyr (1990, p. 291) argued that new technologies emerge as 'hopeful monstrosities': they are 'hopeful', because they look promising, but 'monstrous' because they have crude performance. Subsequent technical improvement, the development of a new body of technical knowledge, and its translation into design rules, technical specifications, models, and rules of thumb often takes a long time.

Second, there may be no immediate market demand for radical technologies, because functionalities are not clearly articulated yet and users are unaware of the technology's potential. Markets, user preferences, and user competences may thus need to be coconstructed with new technologies (Leonard-Barton, 1988; Coombs et al., 2001; Oudshoorn and Pinch, 2003; Linton, 2009). This co-construction process takes time and involves (concrete as well as remote) interactions between producers and users.

\footnotetext{
* Corresponding author. Tel.: +31402474413; fax: +31402444602.

E-mail addresses: r.p.j.m.raven@tm.tue.nl (R.P.J.M. Raven). f.w.geels@tm.tue.nl (F.W. Geels).
}

Third, a broader socio-technical context may need to be constructed in which new technologies can function (Geels, 2004). This may entail the creation of new infrastructures, complementary technologies, symbolic meaning, industry structures, subsidies, and support programmes (often in the initial stages) and appropriate regulations (Kemp et al., 1998).

Crossing the 'valley of death' thus is a difficult process for radical innovations. The approach of strategic niche management (SNM) has addressed this topic, asking the question why many (sustainable) innovations remain on the shelf of R\&D laboratories and do not make it beyond showrooms and exhibitions (Kemp et al., 1998; Raven, 2006; Schot and Geels, 2007, 2008). Earlier work has shown that experimental pilot and demonstration projects in real-life contexts often play an important role in crossing the valley of death (Verheul and Vergragt, 1995; Brown et al., 2003; Engwall, 2003). These projects are sheltered from immediate market selection through subsidies and dedicated support networks. SNM conceptualises these 'protected spaces' as niches where actors can experiment with the alignment between technical variations and (adjustments in) the selection environment. On the one hand, SNM has evolutionary characteristics as suggested by the notions of 'niches' and alignment of 'variation' and 'selection' (see also Schot and Geels, 2007). On the other hand, SNM has aspects of social constructivist theories (Bijker, 1995) as suggested by socio-cognitive dynamics (social network interactions and changes in expectations, beliefs, and perceptions).

With regard to SNM, this article makes two additions:

(1) Articulate more precisely how SNM is embedded in social constructivism and evolutionary economics. This theoretical 
Table 1

Time lag between years of invention and innovation for some new technologies (selection from Clark et al, 1981, pp. 313-314).

\begin{tabular}{lllr}
\hline & Invention & Innovation & Time lag (years) \\
\hline Electronic digital computers & 1939 & 1943 & 4 \\
Float glass & 1902 & 1943 & 41 \\
Fluorescent lighting & 1901 & 1938 & 37 \\
Helicopter & 1904 & 1936 & 32 \\
Jet engine & 1928 & 1941 & 13 \\
Magnetic tape recording & 1898 & 1937 & 39 \\
Radar & 1925 & 1934 & 9 \\
Radio & 1900 & 1918 & 18 \\
Synthetic detergents & 1886 & 1928 & 42 \\
Television & 1923 & 1936 & 13 \\
Transistor & 1948 & 1950 & 2 \\
Zipper & 1891 & 1923 & 32 \\
\hline
\end{tabular}

goal is pursued by combining socio-cognitive and evolutionary theories of technical change.

(2) Show how the end result of this improved conceptualisation can be used to explain different patterns in longitudinal development processes of radical innovations. To this end, we will make a comparative analysis of biogas development in the Netherlands and Denmark (1973-2004).

This article is structured as follows. Section 2 articulates the theoretical foundations of SNM, conceptualising a socio-cognitiveevolutionary process of radical innovation. To demonstrate the usefulness of this perspective, Section 3 uses it to explain the ups and downs and twists and turns in biogas development in two countries. Section 4 provides comparative conclusions.

\section{Socio-cognitive evolution in niche development}

\subsection{Existing building blocks}

Before developing our new conceptual additions, we note two important insights from the literature on which SNM builds. The first insight is that the co-construction of new technologies, markets, regulations, etc. involves processes of learning and experimentation (Thomke, 2003; Watanabe et al, 2009). Experimentation is a special type of learning process that is relevant for exploration (pioneering and development of new technologies). March (1991), who distinguished exploration from exploitation, argued that: "Exploration includes things captured by terms such as search, variation, risk taking, experimentation, play, flexibility, discovery, innovation." (p. 71), and "The essence of exploration is experimentation with new alternatives." (p. 85). Lynn et al. (1996) characterise experimentation with radical innovations as a "probe and learn process':

These companies developed their products by probing initial markets with early versions of the products, learning from the probes, and probing again. In effect, they ran series of market experiments, introducing prototypes into a variety of market segments. (...) Probing with immature versions of the product only makes sense if it serves as a vehicle for learning about the technology, and whether and how it can be scaled up, about the market, (...) and about government regulations and the need for regulatory approvals. (...). Probing and learning is an iterative process." (pp. 15-17).

Concrete real-life projects provide good opportunities for experimentation and probing and learning. It is one thing to make a new idea work in a laboratory, but quite another to achieve the same in real-life contexts. There are technical issues of upscaling and variability of context, and issues related to regulations, user practices, responsibilities, networks, resources, commitments, cultural meaning, and infrastructure. The creation of working configurations on specific locations requires the alignment of these different issues (Fleck, 1994; Leonard-Barton, 1988). Real-life projects function as 'proto-markets', which allow users, producers, and other stakeholders to interact and engage in mutual learning processes. The analysis of concrete projects and practices also draws attention to the content of knowledge and concrete technical problems. As Hård (1994, p. 574) argues:

A practice approach should bring forth the technician as tinkerer (following the 'logic of practice') rather than the engineer as theoretician, and technology as bricolage (informed by 'practical sense') rather than engineering as knowledge production" (italics in original).

SNM scholars have analyzed how sequences of concrete projects may add up to learning trajectories and lead to gradual changes in the content of knowledge, ideas, and perceptions.

A second insight is that learning is not only data accumulation but also sensemaking. Human cognition constructs mental frames and maps of reality (Simon, 1957). These cognitive frames select bits and pieces from the variety of signals that enter the brain, and help to construct meaning. Sensemaking is thus a crucial aspect of cognition (Weick, 1979). Cycles of action, sensemaking, and adjustment of cognitive frames form the basis of cognitiveevolutionary perspectives (Campbell, 1965; Burns and Dietz, 1992; Garud and Rappa, 1994). Weick (1979), for instance, proposed an 'enactment-selection-retention model. On the basis of existing cognitive frames, actors do something in the world. This leads to experiences, which are subsequently interpreted: actors impose meaning upon, and make sense out of, the returning signals. Data that fit cognitive frames are selected, while the rest is edited out. In this cognitive view, selection criteria are not embodied in the external environment, but socially, in actors. Retention occurs as meaningful data are embedded in the cognitive frame. Accumulation of data within a cognitive frame is first-order learning, while alteration of cognitive frames is second-order learning. This evolutionary view is similar to the experiential learning theory (Kolb, 1984), which conceptualises learning as a cycle of cognitive activities: concrete experience, observation and reflection, formation of abstract concepts, and testing in new situations (Fig. 1).

Such a cognitive-evolutionary view is useful for understanding technology development, because it accommodates trial and error, experimentation, and concrete experiences in local projects. This view also complements evolutionary economics. Because evolutionary economics emphasises market selection, it is less applicable in the pre-market phase. Socio-cognitive evolution extends the mechanisms of variation, selection, and retention to this pre-market development phase.

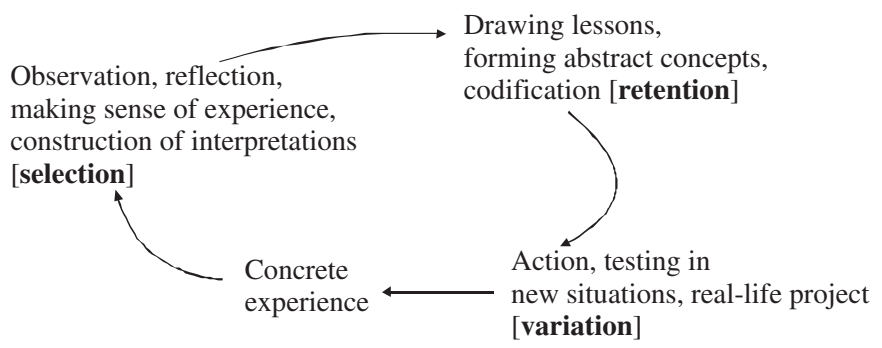

Fig. 1. Experiential learning curve (adapted from Kolb, 1984). 


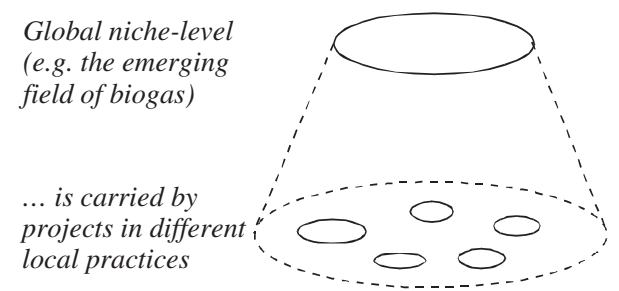

Fig. 2. Local projects and global niche level.

\subsection{Conceptual additions}

The cognitive-evolutionary view, described above, has a focus on individuals, however. To make it socio-cognitive, we make three additional conceptualisations with regard to the mechanisms of retention, variation, and selection.

First, retention requires the conceptualisation of a global level of technological development. ${ }^{1}$ The local level, which was addressed above, concerns local practices, concrete projects, and tinkering with artefacts (technology development as site-specific, messy process of bricolage). But technological development also has predictable and global characteristics. Evolutionary economists point to 'technological regimes' (Nelson and Winter, 1982), the cognitive frames and routines (e.g. search heuristics, exemplars) that are shared in a technical community, and which guide and orient engineering activities. These shared cognitive routines explain why engineers, who work in different local practices, collectively work in the same direction, resulting in technological paths (Garud and Karnøe, 2001). For similar purposes social constructivists coined the term 'technological frame', which consists of problem agendas, problem-solving strategies, search heuristics, theories, testing procedures, and design methods and criteria (Bijker, 1995). This global level of cognitive routines and frames acts as retention mechanism through which communities store accumulating knowledge. Technological development thus proceeds at two levels simultaneously: (1) a local level of projects with concrete artefacts and (2) a global level, consisting of cognitive rules and an emerging community (Fig. 2).

Biogas, for instance, was first carried by a few projects and actors. Gradually, the number of projects proliferated, and the actors began to see themselves as part of the same (emerging) community. They organised workshops, exchanged experiences, wrote reports, discussed results, and thus developed shared problem agendas, ideas, perceptions, and search heuristics. A global level was thus constructed socially and cognitively. With regard to the social dimension, we build on Law and Callon (1992), who distinguish between local and global networks. Local networks consist of actors who work on specific local projects, and a global network consists of the emerging community. This global network also includes actors who are not immediately involved in projects, but provide general resources, such as finance, political support, and technical specifications (e.g. policy makers, professional societies). With regard to the cognitive dimension, we make a distinction between local, site-specific knowledge (skills, hands-on experiences) and global, abstract, generic knowledge that is shared within a community (Hård, 1994). These global cognitive rules are created through aggregation, formalisation, and codification of experiences in local practices (Geels and Deuten, 2006). Retention thus occurs at the global niche level. Shared cognitive rules act as knowledge reservoirs or 'carriers of history' for technology development

${ }^{1}$ The 'global' and 'local' distinctions are not geographical, but sociological, with 'global' referring to field-level dynamics and 'local' to specific local practices (Hård, 1994; Geels and Deuten, 2006). Hence, global does not mean 'international'.
(David, 1994). Global cognitive rules (abstract theories, technical models, problem agendas, search heuristics) form resources and guiding frames for practical activities in local practices. But they leave room for local interpretations and adjustments to meet local circumstances. Hence, there can be variety in local practices and a degree of stability at the global level.

Geels and Raven (2006) called this global level a 'technological niche'. The basic idea is that the emerging community carves out a protected space for the new technology. This protection is needed because 'hopeful monstrosities' cannot immediately compete on mainstream markets. This notion of protecting niches comes from allopatric theory in biological evolution (Mayr, 1963). This theory argues that new species emerge in geographically isolated niches or in niches operating at the periphery of an existing ecosystem. For radical technological evolution such niches do not readily exist, but are actively created.

Variations may impose themselves on the environment. In this sense, niches do not pre-exist, waiting to be filled, they materialize as the product of organizational action. Organizations do not (...) fortuitously fit into predefined sets of niche constraints; rather, they opportunistically enact their own operating domains (Astley, 1985, p. 234).

The technological niche literature looks explicitly at the emergence and creation of niches and new technologies. ${ }^{2}$ Protection in technological niches comes from networks of dedicated actors, who are willing to invest resources in the new technology. High expectations and formal subsidies contribute to this willingness (see also below).

The second conceptual addition is to make variation more sociological. From the community perspective local projects form spaces to experiment, to deviate from existing rules, and generate variety. In biological evolution, mutations are blind. But in the social domain, variation is (at least partly) intentional. Actors have reasons to search in particular directions, even though they cannot fully predict outcomes. Variation is guided by expectations in the form of search heuristics (Nelson and Winter, 1982), strategies, or visions. Expectations are important for technological development for two reasons (Van Lente, 1993; Brown and Michael, 2003; special issue in TASM, 2006, No. 3). First, expectations indicate directions for innovative activities and local projects, as they are translated into search heuristics. Second, product champions use expectations strategically and rhetorically when they make promises to attract attention and resources from sponsors. These expectations take the outside world into account, because promises sketch a future world in which the innovation will function (solve problems, conquer markets). If the outside world changes, this will influence the content of expectations and the resources made available for local projects. Expectations thus mediate between global cognitive rules and local projects and are influenced by the outside world (Fig. 3).

The third conceptual addition concerns selection. Local projects create experiences and outcomes that need to be interpreted and translated into generic lessons that can become part of global cognitive rules. Collective or social learning thus acts as selection mechanism. This learning is not a rationalistic process of data accumulation. Instead, learning that feeds back to the community level is a process of collective and negotiated sensemaking (Weick,

${ }^{2}$ The niche concept is also used by organisational population ecologists (Carroll, 1985). But they focus on the effects of the width of market niches on competition in populations of firms. So the existence of (market) niches is taken as given. The same applies, although to a lesser degree, to some evolutionary economists who emphasise the role of small market niches in nurturing radical innovation (Saviotti, 1996; Frenken et al., 1999). The point is that such dedicated market niches do not always readily exist for new technologies. 


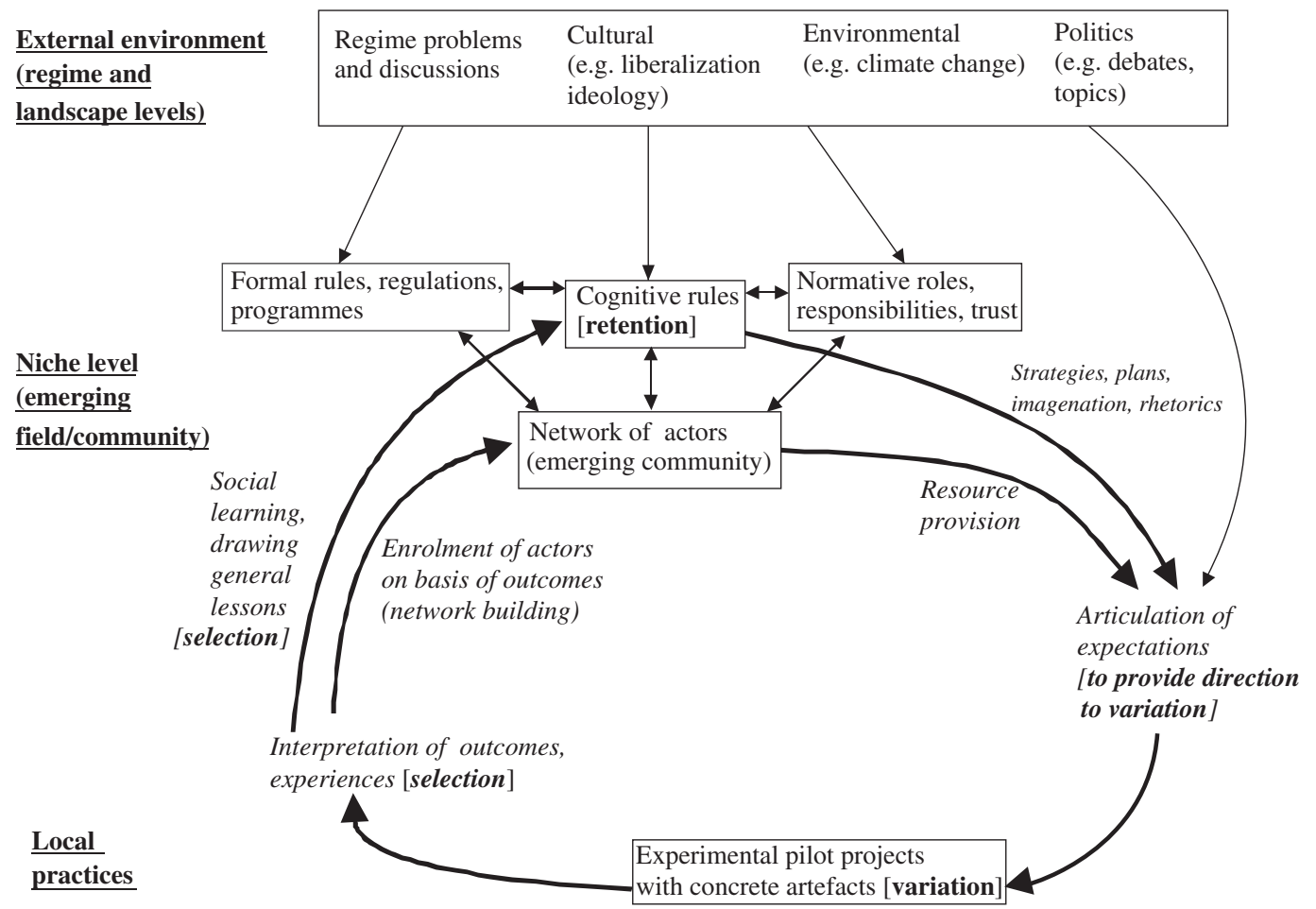

Fig. 3. Dynamics in socio-cognitive technology evolution (adapted from Geels and Raven, 2006, p. 379).

1979). Because of 'interpretive flexibility' (Bijker, 1995), actors may contest interpretations of results and problems. They may ask questions such as:

- How are evaluative questions framed?

- Which aspects are assessed?

- Who performs the assessments?

Collective learning and contestation are played out at workshops and conferences, in journals, through research grants, etc. "Researchers with different beliefs attempt to sway each other with respect to the routines utilized to judge the technology. It is in this sense that technological systems are negotiated. Therefore, competition between different paths occurs not only in the market, but also in the institutional environment" (Garud and Rappa, 1994, p. 347). Selection through social learning and codification is thus a social process.

Based on these three conceptual additions, Fig. 3 presents an improved conceptualisation of socio-cognitive technology evolution. Cognitive rules at the global, community level act as retention mechanism and resources for innovative projects. Expectations help to mobilise resources from social networks and give direction to projects at the local level. These local projects form spaces for variation and tinkering with concrete artefacts in practice. Projects generate outcomes and experiences for local actors. Results from several local projects are discussed, compared, and interpreted. The transformation of local experiences into more generic and abstract cognitive rules is a selection process that requires dedicated socio-cognitive 'work', e.g. aggregation, formalisation, codification (Geels and Deuten, 2006). The adoption of codified lessons at the community level leads to retention as global cognitive rules. These global cognitive rules form resources for a new round of adjusted expectations. If outcomes and lessons are positive, expectations are reinforced and actors are more willing to provide new resources. Positive outcomes also make it easier to enrol new actors and expand the social network, resulting in more resources. If outcomes are much lower than initial, faith in the new technology diminishes and expectations decline, followed by shrinking of social networks and drying up of resources. In response to disappointing outcomes or wider external changes, actors may engage in 'repair work' and come up with changed expectations that promise better results for activities in other directions. In sum, this perspective explains both ups and downs (through resources and size of networks) and twists and turns (changes in direction through altered cognitive rules and expectations).

Fig. 3 acknowledges that external factors at the regime and broader landscape level may influence niche development. This influence acts as 'distal causation' that operates through their effect on expectations and institutional rules (cognitive, normative, and formal), which act as 'direct causation'. The influence of external factors is thus mediated and enacted through the sociocognitive micro-processes.

Building on the neo-institutional literature on organisational fields (Scott, 1995; Powell and DiMaggio, 1991), we distinguish three kinds of institutional rules: (a) normative (role relationships, responsibilities, behavioural norms), (b) formal (regulations, laws, subsidy programmes), and (c) cognitive. Although the socio-cognitive perspective only endogenises cognitive rules, we recognize the influence of normative and formal rules. Hence, they are analyzed in the case study as important factors (especially formal rules). But they are not endogenised in the socio-cognitive perspective. This would require additional theories (e.g. policy networks, governance theories, communities of practice).

Note that this conceptualisation of the global niche level is similar to the conceptualisation of regimes used in the multilevel-perspective on technological transitions (Geels, 2004, 2006), which also distinguishes among normative, formal, and cognitive rules. Niches differ from regimes in: (a) the level of stability of rules (regime rules tend to be much more stable than niche rules) and (b) the size of the social network supporting those rules (regimes are carried and enacted by more actors than niches are). 


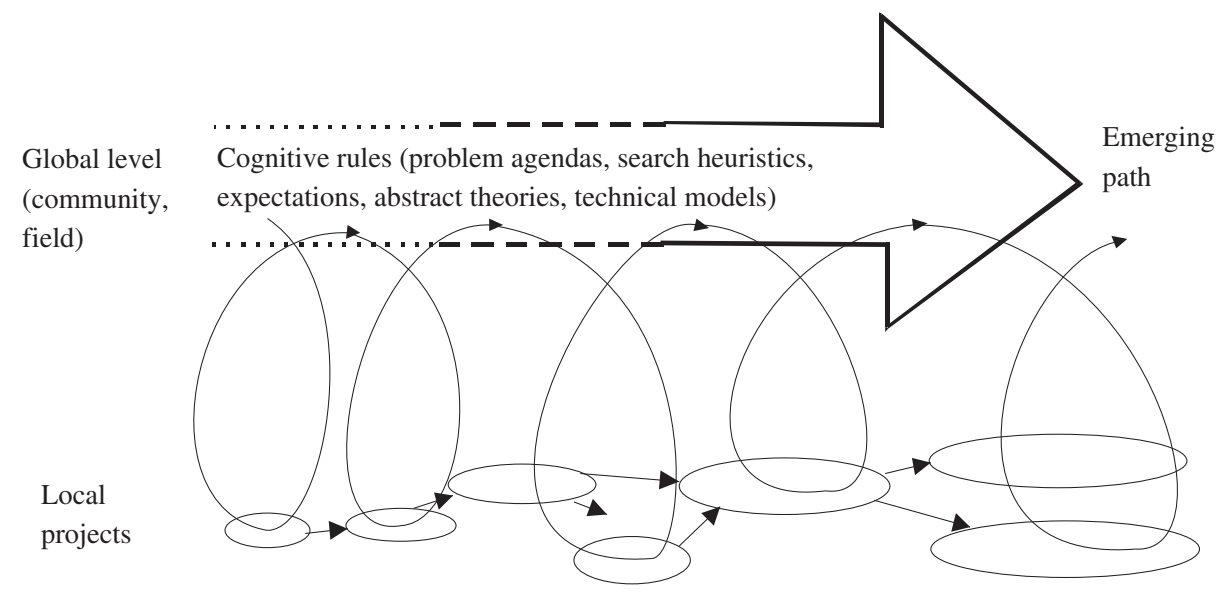

Fig. 4. Emerging technical path carried by sequence of local projects (adapted from Geels and Raven, 2006, p. 379).

The remainder of this article will demonstrate that this sociocognitive-evolutionary conceptualisation is not only an interesting perspective but can also explain particular patterns in niche development, such as the ups and downs and twists and turns in biogas development (Section 3). The case study will show how sequences of concrete local projects gradually add up to a technological path at the global level (Fig. 4). When developments start with a few projects, the global cognitive rules are diffuse and unstable. Further sequences of local projects enable socio-cognitive cycles that lead to further articulation and elaboration of global cognitive rules. As these cognitive rules become more specific and stable, a technological path emerges (Nelson and Winter, 1982; Garud and Karnøe, 2001). These emerging paths will change direction when expectations and cognitive rules are adjusted in response to disappointing outcomes of local projects or changing external circumstances.

\section{Case study of biogas development in Denmark and the Netherlands}

To demonstrate its usefulness, this section uses the sociocognitive evolution perspective to explain the different patterns of biogas development in the Netherlands and Denmark. Many social groups were involved in biogas development: universities, research institutes, technology suppliers, farmers, utilities, different ministries (economic affairs, trade, agriculture, and environmental affairs), municipalities and counties, grassroots movement, chemical companies, banks, and agricultural branch organisations. The case study analyses the interactions between these actors, the learning processes, formulation and adjustments in expectations and cognitive rules, resource provision, and local projects. Also formal regulations (subsidy programmes) and exogenous regime developments are important, but these are not endogenised in the analysis. We will return to this issue in the conclusions section.

The first sub-section below (3.1) describes the two patterns of biogas development in both countries. The other three sections (3.2-3.4) aim to explain the main patterns for both countries. Because of space limitations, the sub-sections do not provide detailed analysis of individual projects, strategies of individual actors, or the contested and negotiated character of social learning and sensemaking. The empirical sub-sections lean heavily on Raven (2005). Empirical data have been collected from various heterogeneous sources, including policy documents, research reports, scientific journals, conference proceedings, minutes and slides from meetings, newspapers, and interviews with involved actors. The case study is divided into three periods: 1975-1985, 1985-1995, and 1995-2003.

\subsection{Contrasting development patterns in the Netherlands and Denmark}

Biogas, a mixture of methane and carbon dioxide, is the end product of manure digestion. The heart of a biogas plant is the anaerobic digester (Fig. 5). Inside the digester, manure is stored for about 3 weeks. In the absence of oxygen, anaerobic microbes convert part of the manure into methane and carbon dioxide. Before manure enters the digester, it is pre-processed to increase homogeneity. One end product of digestion is biogas. Biogas often has small contaminations and needs cleaning before it can be used as an energy source. Biogas can be used in combined heat and power units (CHP), in district heating plants, or for injection in a natural gas grid. The second end product is processed manure, which can be used as a fertilizer. Sometimes, organic waste (e.g. fish oil, corn) is added to the digestion process (up to $25 \%$ of total volume). This increases biogas yields and reduces waste that is otherwise dumped at landfill sites.

Manure digestion exists in two forms. Farmscale plants process manure from a single farm. The resulting biogas is used on site to heat stables or produce electricity, while processed manure is used on the land. Centralised biogas plants are larger and process manure from multiple farms, something that has design consequences for transport and storage. Centralised plants are often operated by dedicated organisations with chemical competencies. The emphasis is broader than biogas production and includes manure processing and production of fertilizer granules.

Biogas, which it is still relatively small in both countries and produces less than $1 \%$ of electricity consumption (Raven, 2005), has experienced a long development path with many ups and downs and twists and turns. In the last 30 years, biogas saw not only substantial changes in technical knowledge and designs but also in ideas about functionality. Figs. 6-9 present biogas developments in the Netherlands and Denmark in terms of the cumulative number of plants and installed digester capacity.

These figures show similarities and marked differences between both countries. One similarity is that developments in both countries began with farmscale plants, sparked off by rising energy prices in the late 1970s. In both countries the number of farmscale plants peaked in the early 1980s and then declined. An interesting contrast is that farmscale plants completely disappeared in the Netherlands, but maintained a foothold in Denmark. Revival of farmscale plants in the late 1990s was much faster in Denmark than in the Netherlands. Another similarity is that 


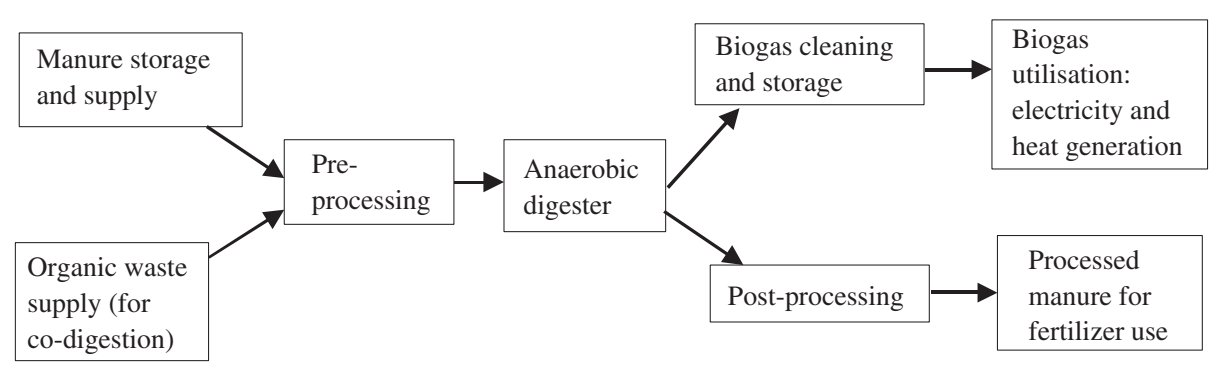

Fig. 5. Basic layout of a biogas plant.

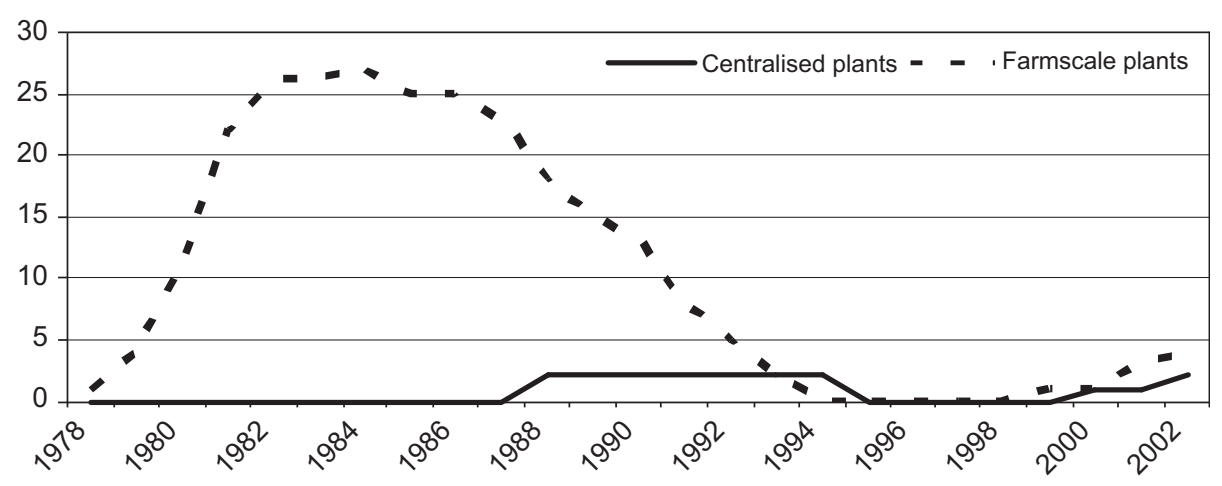

Fig. 6. Accumulated number of Dutch biogas plants.

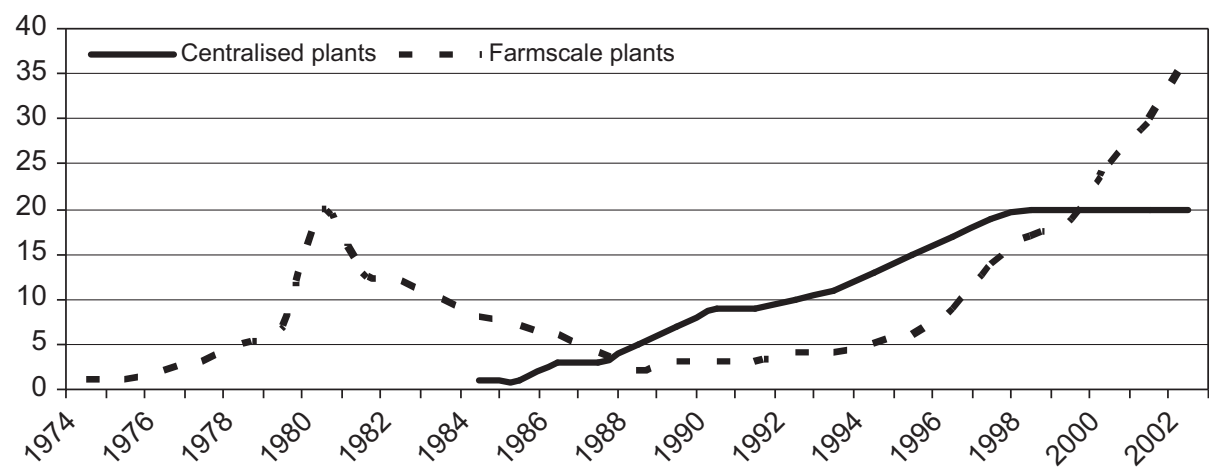

Fig. 7. Accumulated number of Danish biogas plants.

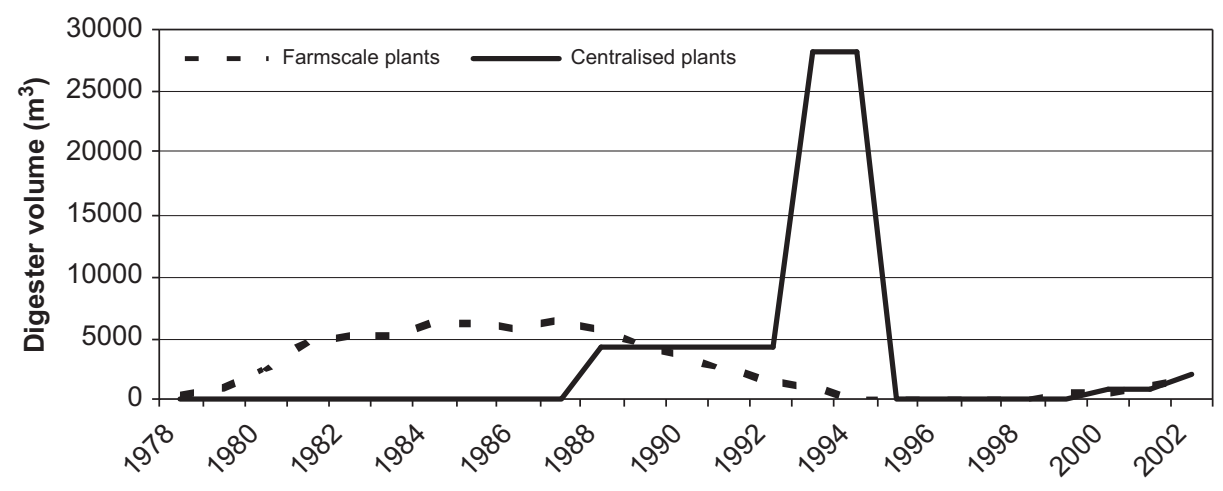

Fig. 8. Accumulated digester capacity $\left(\mathrm{m}^{3}\right)$ of Dutch biogas plants.

centralised plants appeared in both countries in the mid-1980s. A major difference was that the Netherlands built only two centralised plants, one of which had gigantic proportions, signalling a path of rapid upscaling. The failure of this huge centralised plant was followed by a termination of all biogas activities. In Denmark, the number of centralised plants 


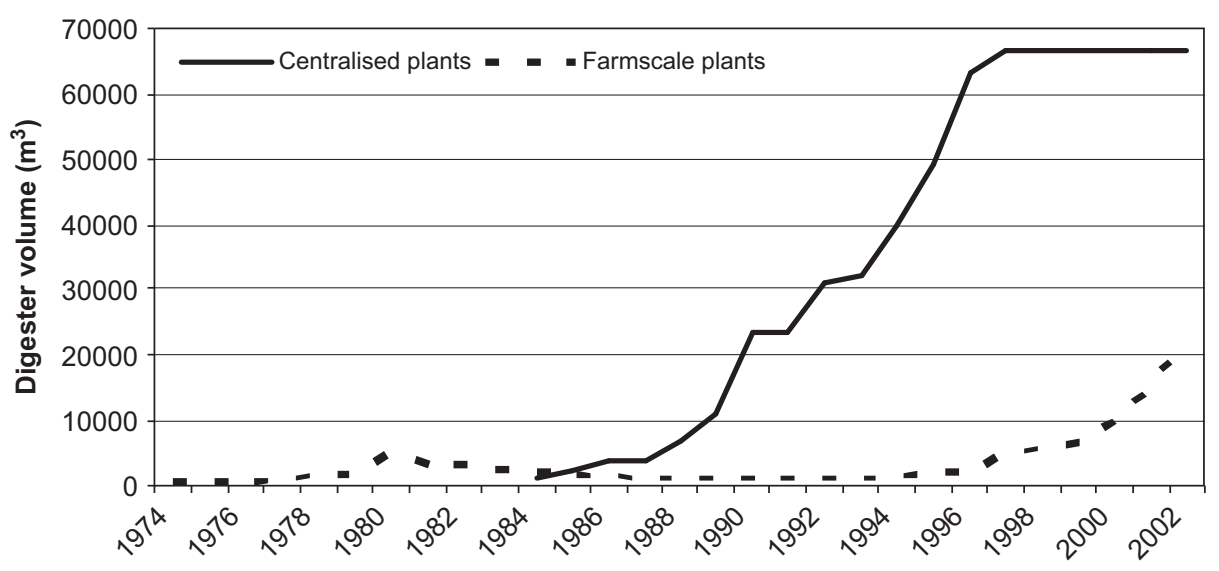

Fig. 9. Accumulated digester capacity $\left(\mathrm{m}^{3}\right)$ of Danish biogas plants.

progressed gradually, did not collapse, and reached a stable plateau in the late 1990s. In the early 2000s Dutch centralised plants reappeared again, but more cautiously than before.

\subsection{The rise of farmscale plants (1975-1985)}

\subsubsection{The Netherlands}

Biogas emerged in the context of high energy prices in the 1970s and 1980s, following two oil crises. Researchers at Wageningen Agricultural University expected that farmscale biogas plants would allow farmers to produce their own energy and reduce costs. Although scientific fundamentals of digestion processes were known, there was no practical design knowledge for biogas plants. Technology suppliers had general agricultural knowledge (e.g. construction of silos), but no specific technical knowledge for biogas plants. Both networks and knowledge thus needed to be constructed. The first dedicated research project began in 1976, focusing on relationships between process parameters (temperature, time) and biogas yields. As part of the project a small pilot plant $\left(270 \mathrm{~m}^{3}\right)$ was constructed with a pig farmer in Garderen in 1979. Biogas was used for heating the farm and stable.

Because outcomes were positive, a 3-year follow-up research programme (1980-1983) was created. The Ministry of Economic Affairs, responsible for energy policy, financed $60 \%$ of the 2.8 million Dutch guilders (1.3 million euros). Ideas about functionality thus focused on cheap alternative energy production. The guiding principle for innovative activities was to optimise biogas yields. Choices about participation in the research programme were based on farm size and energy demand. There was little attention for agricultural benefits like improved fertilizer characteristics of processed manure. Important actors in the emerging global biogas network were researchers from Wageningen Agricultural University. Farmers were also involved as active participants, providing feedback and sometimes co-developing plants with suppliers (Hoek, 1984).

The available resources and high expectations attracted new actors in the network. The number of farmscale plants increased to 26 in 1983. Wageningen researchers monitored the different projects, compared local outcomes, and aggregated general lessons in reports. The programme generated much technical knowledge. Researchers and technology suppliers learned detailed lessons about manure composition, microbiological processes inside the digester, and relationships between temperatures, processing time, and biogas yields. They learned about technical components such as manure storage systems, manure pumps, gas engines, heat exchangers, cutters, mixers, and separation technologies. Several components proved to be vulnerable. The pump that supplied manure often suffered blockage. Devices to stir manure inside the digester worked insufficiently and often broke down. Furthermore, it was learnt that biogas contained small amounts of hydrogen sulphide, which damaged gas engines and transport pipes because of its corrosive properties. A major disappointment was that biogas yields, and thus savings on energy costs, were lower than estimated calculations, in some plants $50 \%$ below initial expectations. As a result, all plants had negative returns on investment.

In response to these disappointing outcomes, researchers argued that technical breakdowns were teething problems, which they would solve in the future. They also did 'repair work' in formulating new expectations. In 1982 Wageningen researchers promised future profitability because of expected rises in energy prices (Werkgroep Bedrijfsopzetten Biogasinstallaties, 1982):

The expectation is that energy prices will increase more rapidly than the costs of biogas plants. The result is that in the future, economic feasibility will increase. [...]. The value of $1 \mathrm{~m}^{3}$ biogas will also increase, due to the expected price increase of domestic fuel oil, and an estimated inflation rate of $5 \%$. For 1982, calculations use a value of 0.52 Dutch guilders; in 1983 the value will already be 0.552 Dutch guilders per $\mathrm{m}^{3}$ manure. In 1985 the value will be 0.615 Dutch guilders and in 1990 the value will be 0.812 Dutch guilders. (...) if these calculations are continued, the value will be 1.608 Dutch guilders per $\mathrm{m}^{3}$ in 2000 !

Researchers also formulated expectations with a new content, arguing that economic feasibility could be improved with bigger, centralised biogas plants that benefited from economies of scale. But these promises were not immediately picked up by other actors. In fact, no new plants were constructed after 1984. The social network gradually weakened as more projects were abandoned. Farmers no longer expected biogas plants to become feasible on the short term.

\subsubsection{Denmark}

In Denmark, biogas was one of the options investigated after the 1973 energy crisis. Farmers, research centres, and new technology companies articulated expectations of a bright future for biogas plants. But there was no experienced social network with dedicated knowledge. A local farmer, Jespersen, constructed the first pilot plant, in cooperation with a local blacksmith, to practically demonstrate basic digestion principles. His initiative was embedded in the Danish grassroots movement, which 
included Folke High Schools, several scientists, local energy offices, and farmers.

In 1978 the Ministry of Trade gave a 3.6 million DKK grant (about half million euro) to the new Cooperation for Technological Development of Biogas Plants (STUB). STUB created a global network to support and assist farmscale plant construction. STUB mobilised expertise from the Danish Technological Institute, agricultural specialists, and engineering firms (such as Carls Bro $\mathrm{A} / \mathrm{S}$ ). Within the STUB programme, seven plants were constructed to learn about technical and economic performance, especially biogas yields and energy generation. STUB engineers collected information from the projects and published it in a magazine (Biogas Nyt). Knowledge was thus explicitly aggregated and circulated within the emerging community (Groen, 1981).

In 1981 an inventory was made of the 21 registered biogas plants (10 were in the STUB programme). All plants had major technical problems and negative economic returns. Because biogas yields were below initial expectations, farmers began to abandon projects. The declining expectations and shrinking networks led to fewer resources. But the niche did not die, because the grassroots movement kept it alive. Especially the Danish Folkecenter, which had strong beliefs in decentralised energy generation, was important. It continued technical development and some implementation, although at a small scale (Groen, 1981).

\subsection{Decline of farmscale plants and emergence of centralised plants} (1985-1995)

\subsubsection{The Netherlands}

The rapid decrease of global oil prices in 1986 further undermined expectations about future economic feasibility of biogas plants in the Netherlands. At a meeting of the Dutch biogas network in 1986, a prominent researcher expressed the general opinion as follows:

Participants' attitudes towards manure digestion are fairly clear. If solely energy generation is considered, the application of manure digestion is not feasible at this time. Neither is improved feasibility likely in the short term. The optimal biogas yields from manure are known, and we cannot foster high expectations about rising gas production from manure (Van Velsen, 1986).

Developments in the agricultural regime, however, created a window of opportunity for centralised biogas plants. The increase in numbers of pigs, chicken, and cows and the application of feeding concentrates with high mineral content resulted in huge problems with manure and mineral surpluses. Agricultural policy makers stimulated three possible solutions: (a) processing of manure and export of product; (b) distribution of unprocessed manure within the Netherlands from regions with a manure surplus to regions with a manure shortage; and (c) reduction of mineral supply into the agricultural system by changing the composition of animal feed.

Influential actors in the agricultural regime perceived centralised manure processing as most promising. Manure digestion was one sub-option besides others, e.g. drying of manure and separation of manure into different fractions. Although manure digestion did not reduce the amount of minerals, it stabilised manure for further processing. Regime actors had particularly high expectations about the production of fertilizer granules that could be exported to southern European markets. These expectations legitimated the construction of a huge centralised digestion plant-Promest. In this plant the functionality of manure diges- tion was no longer linked to energy production (biogas) but to manure processing.

The Promest B.V. Company was established in 1986, supported by a social network that was dominated by established agricultural branch organisations, agricultural policy makers, chemical companies, and financial companies. Researchers from Wageningen Agricultural University were involved, but no longer as dominant actors. The plant's reactor size $\left(4000 \mathrm{~m}^{3}\right)$ was about 15 times larger than that of the average farmscale digester, and designed to process 100,000 tons manure annually. The plant design also used various new technologies, some of which came from chemical and food industries. Initial construction costs were high -23 million guilders ( 10 million euros), But actors in the Promest support network made optimistic claims about future profitability. Researchers doubted the figures, but were ignored (Bloemendaal, 1995).

Promest was based on an innovative design (two-phase digester), dividing the digestion process into two steps. The first digester tank $\left(1000 \mathrm{~m}^{3}\right)$ should capture most of the corrosive hydrogen sulphide, while the second tank $\left(1000 \mathrm{~m}^{3}\right)$ should produce clean biogas. This design was expected to reduce purification costs for hydrogen sulphide. The design also included a third, conventional digester $\left(2000 \mathrm{~m}^{3}\right)$. The produced biogas could be used for heating purposes, thus reducing the plant's overall energy demand. The manure leaving the digesters was to be processed into a solid fraction, which was mixed, dried, and palletised, resulting in the main product-fertilizer granules.

The plant began operation in 1988 , but soon experienced difficulties. Operators learned that heat exchangers did not sufficiently warm the manure inside the digester tanks. The chopper that cut large parts (e.g. straw) into smaller parts got stuck. An unexpected scum layer formed inside the digester, causing blockages. Anti-scum substances existed, but were expensive. The innovative two-phase digester design did not work well, and the biogas from the second digester still contained high levels of hydrogen sulphide. Hence, an [expensive] caustic bath was installed to remove hydrogen sulphide. Promest also learned that the product (fertilizer granules) was chemically unstable and could spontaneously burst into flames. This happened in 1992 on a transport ship to Spain and Portugal. Furthermore, sales were low, because of southern European farmers' unfamiliarity with the product (Bloemendaal, 1995).

These learning processes seemed to be disconnected from decision-making processes. Agricultural regime actors expected that the government would intervene strongly if manure problems were not solved. Hence, they decided in 1990 to expand Promest's capacity from 100,000 to 600,000 tons of manure per year. Researchers warned against this plan, pointing to negative outcomes of learning processes. But these warnings were neglected. Seven new digesters were installed, increasing total investment costs to more than 100 million Dutch guilders (45 million euros), $40 \%$ of which came from the Ministry of Agriculture. In 1993 the new plant was opened. But outcomes remained problematic with regard to: (a) technical design of digester tanks, separation technologies, and dryers, (b) process conditions and operating characteristics, (c) market demand, and (d) sufficient and reliable manure supply. Economic losses sky rocketed and the plant was shut down in late 1994. This big and costly failure led to very negative expectations about manure digestion, and withdrawal of support and resources. This coincided with the failure of a second centralised biogas plant.

Deersum, a small village of 115 inhabitants, had problems with the sewer system. Discussions led to a plan for the self-generation of electricity, using a wind turbine and a centralised biogas plant. The European Commission, the Ministry of Environment, and the province of Friesland helped to finance the biogas project, based 
on sewage and manure. There was some continuity, because the plant supplier and involved research institute had also worked with biogas plants in the early 1980s. The design was similar to those of previous biogas plants. The centralised plant was small $\left(210 \mathrm{~m}^{3}\right)$, with seven farmers supplying manure. Construction started in 1986 and operation began in 1988. The plant soon experienced technical problems. Although pressing problems were solved during the first year, frequent repairs remained necessary. Biogas yields were half of what was expected. Evaluations indicated that costs for self-generated electricity would probably remain higher than normal electricity prices. Nevertheless, Deersum farmers continued the biogas plant until 1995. The main reason was that second-order learning processes changed their ideas about functionality. While these ideas initially focused on renewable energy, farmers gradually learned about the benefits of centralised manure storage, the possibility of reducing artificial fertilizer use, and easier handling of digested manure. Visits to Denmark also brought the idea that biogas yields could be substantially improved by adding organic waste to the digestion process (co-digestion). But when Deersum farmers wanted to introduce co-digestion in 1995, they faced opposition from the Province of Friesland. The Province had just invested in a new collection and processing infrastructure for household waste, and opposed the use of this waste for co-digestion. This was the deathblow for Deersum farmers, who lost the will to overcome technical and economic barriers.

So, by 1995, Dutch biogas development was grounded to a halt. Failed projects and disappointing learning processes resulted in negative expectations about manure digestion. Supporting networks and resources dried up.

\subsubsection{Denmark}

In Denmark, researchers used negative lessons from farmscale projects to change direction and develop new, positive expectations about centralised biogas plants. They argued that bigger plants could reduce production costs and increase biogas yields. They also claimed benefits from the fact that centralised plants would move operational responsibilities from individual farmers to professional firms. These new expectations, which emerged before oil prices dropped in 1986, were picked up by municipalities, who were looking for alternative fuels to fire local heating networks.

A Danish county in the North of Jutland implemented the 'Village Energy Project'. The first centralised biogas plant was built in 1984 in the town Vester Hjermitslev (Seadi, 2000). The aim was to become self-supporting in energy. Most costs were covered by a four million DKK grant from the government and an 8.4 million DKK loan from the North Jutland County Council (together about 1.5 million euros). In 1985, a second centralised plant was constructed in Vegger. The design was similar to the first plant, but operating temperatures were higher $\left(55\right.$ instead of $\left.35^{\circ} \mathrm{C}\right)$. This variation meant that an extra pasteurisation step could be left out. A third plant was constructed in Skovsgård.

Experiences with the plants were disappointing. The first plant encountered problems with the gas transport system, heat pump and pre-sanitation step (to kill pathogens). Reconstruction in 1988-1989 improved the plant's performance substantially. The other two plants encountered fewer problems, but biogas production remained below expectations. Hence the North Jutland County withdrew support for biogas technology. The social network that carried the niche threatened to fall apart.

Changes in the energy and agricultural regimes created new opportunities after 1985. In the energy regime, the government rejected nuclear power and expanded the use of domestic fossil fuels (mainly natural gas from the North Sea), wind power, and biomass applications. Natural gas was to be used for decentralised combined heat and power units (CHP). But about a quarter of Danish regions were not connected to the natural gas infrastructure. In these regions, the government expanded its support for biomass, including biogas plants. Decreasing oil prices after 1986 threatened to frustrate this energy strategy. To prevent the reintroduction of oil, the government raised taxes on oil products, coal, and electricity. Renewables (including biogas) and natural gas were exempted from this tax. This made energy from biogas more competitive in Denmark than in other European countries.

Around the same time, the Danish agricultural regime faced manure and mineral problems. A 1984 report from the Danish Environmental Protection Agency (EPA) triggered a societal debate, which led to stricter agro-environmental rules. Farmers were allowed to distribute manure on the land only in periods when the risk of nitrate leaching was low. They had to store manure for the remainder of the year. Farmers had to build storage capacity for 6-9 months of manure production. In 1987, the EPA published the Water Environment Action Plan I, which included a major reduction goal for nitrate leaching from agriculture. This plan regulated the number of animals per hectare as well as the maximum input of nitrogen per hectare. This created problems for many farmers. One option to deal with surplus manure was to participate in centralised biogas plant organisations. These organisations could collect, transport, store, and redistribute manure for farmers.

These regime changes boosted the expectations for centralised biogas plants. Hence, new actors joined the niche. To further stimulate centralised biogas plants, the Danish Energy Agency (DEA), the EPA, and the Ministry of Agriculture established the Biogas Action Programme in 1988. This programme created a global network through research and development activities, construction and monitoring, and information activities. It also included an investment grant for centralised biogas plants (up to $40 \%$ of costs) and a loan scheme with low interest rates. The programme initially ran between 1988 and 1991, but was continued until 2002.

The Biogas Action Programme followed a bottom-up approach, constructing one or two centralised biogas plants annually (Seadi, 2000). This constituted a learning trajectory, allowing actors to build on previous learning experiences. The programme also facilitated interactions in the social network, involving policy makers, farmers, researchers, biogas plant suppliers, and biogas plant operators. Regular meetings and workshops stimulated the emergence of a biogas community and rapid diffusion of experiences and innovations, such as a biological gas purification system based on adding a little air. Learning processes were broad, focusing also on behavioural and sanitary issues. Centralised biogas plants led farmers to change their routines with regard to manure distribution on the land, using less artificial fertilizer. The Ministry of Agriculture implemented several research projects on sanitation and pathogens to investigate risks of spreading animal diseases. This led to a measurement method to determine the presence of pathogens in digested manure. This method was applied in biogas plants in 1994 and improved operating conditions. Research also produced detailed knowledge about relationships between temperatures, residence time, and pathogen kill-off in biogas plants. This knowledge was used to specify sanitation regulations for waste products. The new regulations were more flexible and tailored to different operating characteristics. In sum, learning processes were broad, addressing technical, scientific, user, regulatory, and environmental dimensions.

One important lesson was that biogas yields were substantially increased by co-digestion, i.e. addition of small amounts of organic waste (in particular fatty waste and fishery waste) to manure. Co-digestion also improved economic feasibility, because 
biogas plants received the gate fee for processing waste that was otherwise dumped at landfill sites. Co-digestion helped strengthen the social network, because it made biogas plants interesting for three regimes and ministries: it produced renewable energy, which was interesting for the DEA; it reduced organic waste, which was interesting for the EPA; and it processed manure streams, which was interesting for the Ministry of Agriculture.

A specific aspect was the formation of well-functioning local networks, in the form of farmers' cooperatives (5-100 farmers). The cooperative organisation fitted well with the Danish cultural preference for bottom-up collectives. These cooperatives transported and distributed manure, and constructed local storage facilities near farmer's fields. The non-profit cooperatives were financed with loans and grants from the government. They also earned money from energy sales and gate fees. The cooperative form enabled farmers to process manure without paying.

Expectations, resources, learning processes, codification, and network building reinforced each other, creating internal momentum. Performance of centralised biogas plants improved, resulting in better economic feasibility (Fig. 10).

\subsection{Difficult revival (1995-2003)}

\subsubsection{The Netherlands}

Following the Promest disaster, no new biogas plants were constructed in the Netherlands between 1995 and 1998. Biogas was supported only by a loose network of research institutes, consultancies, and small technology suppliers. These advocates formulated new expectations, pointing to positive learning processes and developments abroad. In Germany and Denmark, technical, environmental, and agricultural performance of biogas plants was improved in the mid-1990s: (a) co-digestion increased biogas yields, (b) a new, inexpensive biological purification system removed hydrogen sulphide contaminations, (c) artificial fertilizer use could be reduced, because processed manure had better fertilizer characteristics, since it was more homogeneous; crops also absorbed processed manure better, because minerals were no longer attached to organic matter, (d) processed manure had less pathogens and weeds if digestion occurred at high temperatures, and (e) biogas plants reduced greenhouse gas emissions because methane was collected and used (Van den Broek et al., 2002).

Advocates also incorporated new ideas about functionality in the new expectations. While previous ideas had focused on single functionalities (energy generation, reduced manure problems), new ideas highlighted the multi-functionality of manure digestion: (a) make agriculture more sustainable by reducing artificial fertilizer use, (b) reduce methane emissions, and (c) produce renewable energy.

These new promises were not immediately embraced, because previous disappointments had led to strongly negative beliefs ('biogas is a disaster'). But developments in electricity and agricultural regimes created windows of opportunity. As climate change rose on the problem agenda, electricity companies developed a new marketing concept: 'green electricity', generated from renewable sources. From 1996 to 2002 the government stimulated green electricity with demand-side subsidies. Consumer interest increased rapidly from 25,000 in 1997 to 1,000,000 in 2000. This boosted energy companies' interest in renewable energy options, including biogas.

In the agricultural regime, manure and mineral problems became less prominent, because of national distribution schemes for unprocessed manure and decreasing numbers of pigs and cows (because of animal deceases, international competition, and decreasing European subsidies). But agricultural methane emissions became a new problem. Following the 1997 Kyoto protocol,

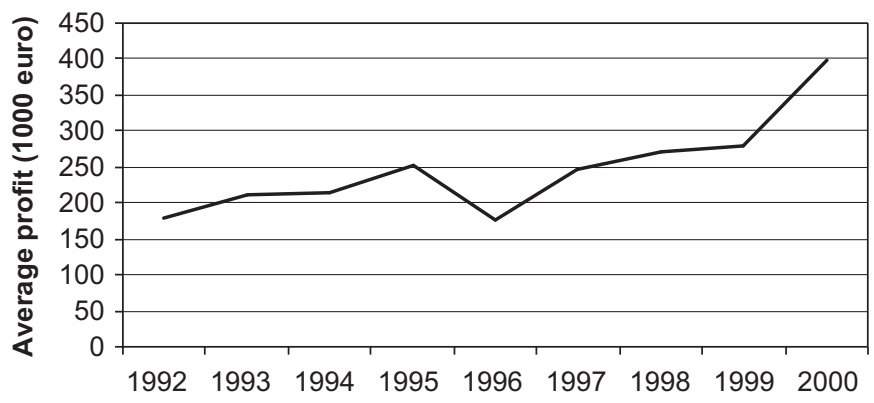

Fig. 10. Average annual profit of centralised biogas plants (not including payment of loans; Hjort-Gregersen, 1999).

the Environmental Ministry developed a climate policy (1999) that also aimed to reduce methane emissions, a strong climateforcing gas. A 200-million euro research programme was established to explore options to reduce non- $\mathrm{CO}_{2}$ greenhouse gasses. Biogas was one such option.

Expectations and networks grew stronger in this context, leading to new resources. New biogas projects were started in the late 1990s. Technological improvements abroad and new ideas of multi-functionality legitimated expectations that manure digestion had better chances. The social network behind the projects was diverse and included energy companies, local farmers, agricultural branch organisations, manure distribution companies, researchers, technology suppliers, and the Ministry of Environment. Much knowledge had been lost in the previous years without practical activities. To acquire expertise old and new companies cooperated with universities and German or Danish firms.

Between 1998 and 2003, two new centralised biogas plants and four farmscale plants were constructed. Multi-functionality formed the main vision behind the two centralised plants. Electricity companies were involved because of their interest in renewable energy, and manure distribution companies were involved because of their interest in the agricultural benefits of processed manure and the reduction of methane emissions. Both projects showed that technical performance had indeed improved: co-digestion improved biogas yields and incomes from energy sales; the biological purification system efficiently removed hydrogen sulphide; and processed manure proved to have agricultural benefits. The processing of manure proved more difficult, however. The transformation of wet manure slurries into a dry, homogeneous, and manageable product required complicated separation techniques, e.g. centrifugation to create a liquid and solid fraction, reversed osmosis, and an ultra-filter to further clean the liquid fraction. The reversed osmosis unit and ultra-filter proved vulnerable to blockages and breakdowns. Because of these mixed results, actors were unsure if benefits outweighed the problems.

The main idea behind the farmscale plants was renewable energy generation. Complicated separation technologies were not needed for these plants because they focused less on manure processing. Using a German design, a plant in Denekamp produced more biogas than expected-about $26 \mathrm{~m}^{3}$ biogas per $\mathrm{m}^{3}$ manure. This was much more than the average performance in the 1980 s, which was $13-15 \mathrm{~m}^{3}$ biogas per $\mathrm{m}^{3}$ manure. Subsequently, three projects were sponsored (Sterksel, Hengelo, Goutem). They aimed to further specify process parameters, further explore co-digestion, and investigate economic feasibility. All projects showed good technical performance and biogas yields that were equal or higher than expected.

But regulatory problems hindered the use of co-digestion with organic waste. Laws stated that manure could be used as fertilizer 
on lands only if it was without other forms of waste. In 2000, a policy decision allowed co-digestion for new biogas plants. But entrepreneurs had to show a sample of the end product, before they would receive a permanent permit. This strange procedure created uncertainty for investors and long delays in permit procedures. Lobby groups organised meetings where farmers and researchers discussed these problems with representatives from the ministry. Eventually the minister created a list of organic waste substances that could be used without a permit.

Problems also came from changes in the financing scheme of renewable energy (REB), which was based on tax exemptions for users of green electricity. Investors perceived this demand-side scheme as uncertain and dependent on changing political preference. This uncertainty frustrated renewable energy investments, including manure digestion. In 2003, the REB scheme was indeed replaced by a new scheme, that guaranteed a premium tariff for a period of 10 years. This created long-term certainty for investors.

The removal of these barriers created a new wave of expectations for biogas plants. In 2003 and 2004 several new projects were started and more applications were in the pipeline.

\subsubsection{Denmark}

By the mid-1990s, Danish centralised biogas plants were ready for take-off. This did not occur, however, because of changes in the energy regime following liberalisation processes. In 1996, the government passed an amendment to the Danish Electricity Supply Act to permit private companies and distribution companies to buy power from third parties. In 1999, Parliament accepted the Energy Reform Act, stipulating further transformations after 2003. This included changes in renewable energy stimulation. Traditionally, the long-term fixed subsidy for renewable electricity was between $€ 0.06$ and 0.075 per $\mathrm{kWh}$. The new act would replace this fixed-price scheme with 'green certificates', the price of which depended on supply and demand. Further uncertainty was related to the introduction of these new rules. Because a green certificate market was not expected to be fully operational before 2005, there were uncertainties for the intermediate years.

These ongoing and anticipated regulatory changes created uncertainties that halted investments in new centralised biogas plants. Despite major improvements in technological and economic performance, no new centralised biogas plants were constructed after 1998. Another problem was that organic waste for co-digestion became scarcer and more expensive as more biogas plants used it. The election of a new liberal/conservative government in 2001 created further problems. Many grants and support schemes for renewable energy were cancelled and replaced by more generic and market-oriented joint implementation and clean development mechanisms. The Biogas Action Programme was terminated in 2002.

Meanwhile, farmscale plants, which had been kept alive by the grassroots movement, experienced a revival because of three reasons. First, farmscale designs were technically improved through continued local testing and learning in the Folkecenter's facilities. Folkecenter's engineers also cooperated with experts from the German biogas industry. The improved farmscale plants were commercialised in 1995 by a new company, 'Dansk Bioenergy A/S', a spin-off from the Folkecenter. Second, agricultural restructuring had resulted in larger average farms with more animals. Economies of scale improved the economic feasibility of farmscale plants. Third, following the 1997 Kyoto protocol, the Danish government implemented the second Action Plan on the Aquatic Environment in 1998. This plan aimed to reduce methane emissions from agriculture. Previous projects had demonstrated not only increases in farmscale performance, but also that high investment costs hindered diffusion. Once the government made investment grants available in 1998 (up to $40 \%$ of costs), farmscale plants diffused rapidly.

\section{Conclusions}

The aims of this research were: (1) to articulate more precisely how SNM is embedded in social constructivism and evolutionary economics and (2) to show how the end result of this improved conceptualisation can be used to explain differences in longitudinal development patterns of radical innovation. The first aim was addressed in Section 2. Regarding the second aim, we draw the following conclusions.

First, the socio-cognitive evolution perspective not only provides an interesting general perspective on niche development but also specific explanations for particular patterns. A comparative analysis of biogas development in the Netherlands and Denmark shows that the differences in patterns can be explained with the specified micro-processes: articulating expectations to provide direction to variation, the building of local and global social networks, and selection as a social learning process, and the retention of lessons to a global level of cognitive rules provides sufficient explanations for understanding. This is demonstrated in the following box (Box 1).

Second, this comparative analysis replicates the bricolage and breakthrough patterns that Garud and Karnøe (2003) found for wind turbine development in Denmark and California. Denmark followed a bricolage pattern (modest steps, low-tech, bottom-up experimentation, gradual upscaling), while America followed a breakthrough pattern (big steps, high-tech, leap-frog idea, rapid upscaling). In our cases these patterns were particularly visible with regard to centralised biogas plants (1985-1995). The Netherlands followed a breakthrough approach in the Promest mega-project. High commitments prevented the recognition of setbacks, something that contributed to its eventual failure. Danish actors applied a modest, bricolage approach, characterised by a heterogeneous, bottom-up network, interactive learning, and gradual building on lessons-learnt. As with wind turbines, the bricolage approach proved more successful for biogas development than the breakthrough approach.

One qualification of our conclusions is that the endogenous interactions between the micro-processes are necessary, but not sufficient to explain the different patterns. As indicated in Fig. 3, external regime developments are also important. The case study showed several important differences in energy and agricultural regimes, which affected biogas development in both countries (see Box 2). Broader national energy and agricultural regimes thus form important additional factors to explain niche development paths. These distal causations are mediated, however, through the sociocognitive micro-processes (which provide direct causation). Both explanations thus complement and need each other.

A second qualification concerns normative and formal rules, which are also important institutions in emerging technical communities (see Fig. 3). The case studies particularly showed the importance of formal rules. Subsidy schemes and investment grants played a role in both countries in the entire period. In the Netherlands, however, this financial support was more ad hoc than in Denmark, where it was part of dedicated support programmes (the STUB programme in late 1970s and the Biogas Action Programme in late 1980s and 1990s). In Denmark, support thus had a more long-term and sustained character than in the Netherlands. This was certainly an important factor for the relative Danish success (besides learning styles, types of networks, and expectations). The socio-cognitive evolution perspective (Fig. 3) acknowledged formal regulations and policy support as important factors, but did not endogenise them. This would require additional theories (e.g. policy networks, governance theories, communities of practice, 
Box 1-A strategic niche management narrative explaining the different patterns in Dutch and Danish biogas developments.

In both countries, the number of farmscale plants expanded in the late 1970s. High energy prices created high expectations about viable energy production with biogas. This expectation led to resources for projects that were carried by an emerging global network of researchers, farmers, technology suppliers, and Ministries of Trade (DN) and Economic Affairs (NL).

In both countries outcomes of learning processes were lower than expected, leading to a decline in the number of farmscale plants after a peak in the early 1980s. In the Netherlands, the steeply declining oil price (after 1986) contributed to declining expectations and eroding networks for farmscale plants. By 1994, farmscale plants had disappeared completely. In Denmark, the global network also weakened because of disappointing learning processes and declining oil price. But farmscale plants were kept alive by a dedicated local network around the Folkcentre, which continued innovative activities because of strong visions about decentralised energy generation. In Denmark, researchers translated the farmscale lessons into new expectations about centralised digestion (economies of scale). Danish municipalities constructed the first three centralised plants in 1984 and 1985. Expectations were strengthened when centralised digestion became linked to manure problems in the agricultural regime and to the government's new energy strategy (1985), based on natural gas and renewables (for regions not linked to the gas grid). In the Biogas Action Programme (1988) the number of centralised plants progressed gradually, reaching a stable plateau in the late 1990s. Danish developments were successful because learning processes proceeded through gradual upscaling and were broad, addressing multiple dimensions. This resulted in new ideas about multi-functionality. The centralised plants were carried by small farmer cooperatives. This made the social network more heterogeneous than in the Netherlands, where big regime actors dominated centralised biogas development. The Dutch development pattern was very different, because of different learning processes, expectations, and social networks. Researchers formulated new expectations about centralised digestion, but these were not picked up until 1987. Subsequent developments followed a boomand-bust pattern. One of the two Dutch centralised plants (Promest) had gigantic proportions, signalling a path of very rapid upscaling. The expectation of centralised digestion became linked to the major manure problems in the agricultural regime. Ideas about functionality thus shifted from energy production to manure processing. The social network consisted of agricultural regime actors with much money and high legitimacy problems (manure problems). Learning processes in the Promest plant focused on techno-economic optimisation and were narrow-setbacks were neglected by the main actors. Further upscaling in 1993 did not overcome the problems and the Promest plant was shut down in 1994. This failure destroyed all expectations about biogas development, and local and global networks for both centralised and farmscale plants disappeared.

Further diffusion of Danish centralised plants was halted in the late 1990s by uncertainties related to liberalisation of the energy regime. Other external developments (new investment policies related to climate change) created new opportunities for farmscale plants, leading to new expectations. Because a dedicated local network had kept farmscale plants alive, their revival in the late 1990s was much faster than in the Netherlands. In the early 2000s, centralised and farmscale plants reappeared in the Netherlands, but more cautiously than in Denmark. Renewed expectations were based on the lessons learned abroad (new technical designs, multifunctionality), new policies regarding climate change, and sustainable energy markets. Rapid breakthrough was hindered, however, by regulatory confusion (permits for co-digestion) and uncertainties related to renewable energy subsidies.

Box 2-Relevant differences in Dutch and Danish energy and agricultural regimes.

One difference concerns the natural gas infrastructure. In the Netherlands, large natural gas supplies were found in the late 1950s. When interest for biogas emerged in the late 1970 s, the whole country was already covered with an extended natural gas grid and consumers had invested in individual natural gas equipment for cooking and heating. Hence there was little opportunity to link biogas to heat generation, because this function was already fulfilled by natural gas. Denmark, in contrast, did not begin introducing natural gas until the 1980s. Hence many areas were not linked to the natural gas grid. These locations were often covered with local heat infrastructures, based on oil-based district heating plants. Government policy was to replace oil with biogas and use the existing plants and infrastructures for heat distribution.

Second, governments reacted differently to decreasing oil prices in the late 1980s. While the Dutch government embraced lower prices to stimulate energy-intensive industry in a period of limited economic growth, the Danish government introduced high taxes on fossil fuels to improve the competitive conditions for domestic energy sources and stimulate the development of new industries. A third difference occurred in the agricultural regime in the late 1980s. Having more animals per capita, Dutch manure surplus problems were larger than in Denmark. This created high pressure on Dutch agricultural regime actors and partly explains their commitment to the breakthrough approach in centralised biogas plants (Promest).

agenda setting, policy learning). It would be insufficient to relate formal regulations and policy simply to lobbying from product champions and industry spokesmen. The case studies showed that policy support was usually linked to broader regime developments (e.g. energy strategy, manure problems, climate change, liberalisation). Also endogenous dynamics in the policy domain are important, but this falls outside the scope of our socio-cognitive technology evolution perspective. Although not everything was endogenised (something that no theory can do), the socio-cognitive evolution perspective captured the main dynamics of niche development, explaining the characteristic patterns of Danish and Dutch biogas pathways. 
One interesting direction for future research is to better understand the determining causes for success and failures in different phases of niche development (see also Jacobson and Bergek, 2004, who distinguish between a formative stage and a growth stage of technological innovation systems). Our case suggests that in early phases external (regime and landscape) changes were important to initiate a process of niche development. After the initial trigger, good management of internal niche processes (learning, expectation management, and social network dynamics) became more important to nurture and develop the niche towards more momentum, which allows it to survive on its own (the formative stage in terms of Jacobson and Bergek). External regime and landscape dynamics became important again when the niche was at the verge of breakthrough (the growth stage in terms of Jacobson and Bergek), or to revitalize a dormant niche (as in the Dutch case).

Another interesting direction for future research is the relation between niche development paths and broader national characteristics such as public attitudes towards technology and innovation, political discourses, and trust relationships between government, market, and civil society. While this article has attempted to contribute to such cross-national comparisons, this remains an underdeveloped area in SNM and MLP studies.

\section{References}

Astley, W.G., 1985. The two ecologies: population and community perspectives on organizational evolution. Administrative Science Quarterly 30, 224-241.

Bijker, W.E., 1995. Of Bicycles, Bakelites and Bulbs: Towards a Theory of Sociotechnical Change. The MIT Press, Cambridge, MA and London, England.

Bloemendaal, F., 1995. Het Mestmoeras. SDU Uitgevers, The Hague.

Brown, N., Michael, M., 2003. The sociology of expectations: retrospecting prospects and prospecting retrospects. Technology Analysis \& Strategic Management 15, 3-18.

Brown, H.S., Vergragt, P., Green, K., Berchicci, L., 2003. Learning for sustainability transition through bounded socio-technical experiments in personal mobility. Technology Analysis \& Strategic Management 15, 291-315.

Burns, T.R., Dietz, T., 1992. Cultural evolution: social rule systems, selection and human agency. International Sociology 7, 259-283.

Campbell, D.T., 1965. Variation and selective retention in socio-cultural evolution. In: Barringer, H.R., Blankenstein, G.I., Mack, R.W. (Eds.), Social Change in Developing Areas: A Reinterpretation of Evolutionary Theory. Schenkman, Cambridge, MA, pp. 19-49.

Carroll, G.R., 1985. Concentration and specialization: dynamics of niche width in populations of organizations. American Journal of Sociology 90, 1262-1283.

Clark, J., Freeman, C., Soete, L., 1981. Long waves, inventions and innovations. Futures 13, 308-322.

Coombs, R., Green, K., Richards, A., Walsh, V. (Eds.), 2001. Technology and the Market: Demand. Users and Innovation. Edward Elgar, Cheltenham, UK.

David, P.A., 1994. Why are institutions the 'carriers of history'? Path dependence and the evolution of conventions, organizations and institutions. Structural Change and Economic Dynamics 5, 205-220.

Engwall, M., 2003. No project is an island: linking projects to history and context. Research Policy 32, 789-808.

Fleck, J., 1994. Learning by trying: the implementation of configurational technology. Research Policy 23, 637-652.

Frenken, K., Saviotti, P.P., Trommetter, M., 1999. Variety and niche creation in aircraft, helicopters, motorcycles and microcomputers. Research Policy 28, 469-488.

Garud, R., Rappa, M.A., 1994. A socio-cognitive model of technology evolution: the case of cochlear implants. Organization Science 5, 344-362.

Garud, R., Karnøe, P., 2001. Path creation as a process of mindful deviation. In: Garud, R., Karnøe, P. (Eds.), Path Dependence and Creation. Lawrence Earlbaum Associates, Mahwah, NJ, pp. 1-38.

Garud, R., Karnøe, P., 2003. Bricolage versus breakthrough: distributed and embedded agency in technological entrepreneurship. Research Policy 32, 277-300.

Geels, F.W., 2004. From sectoral systems of innovation to socio-technical systems: insights about dynamics and change from sociology and institutional theory. Research Policy 33, 897-920.

Geels, F.W., 2006. Co-evolutionary and multi-level dynamics in transitions: the transformation of aviation systems and the shift from propeller to turbojet (1930-1970). Technovation 26 (9), 999-1016.
Geels, F.W., Raven, R.P.J.M., 2006. Non-linearity and expectations in nichedevelopment trajectories: ups and downs in Dutch biogas development (1973-2003). Technology Analysis \& Strategic Management 18, 375-392.

Geels, F.W., Deuten, J.J., 2006. Local and global dynamics in technological development: a socio-cognitive perspective on knowledge flows and lessons from reinforced concrete. Science and Public Policy 33, 265-275.

Groen, G., 1981. Biogas Technology in Denmark. Carl Bro International, Glostrup.

Hjort-Gregersen, K., 1999. Centralised Biogas Plants. Danish Institute of Agricultural and Fisheries Economics, Copenhagen.

Hoek, K.W., 1984. Methaangaswinning en -Benutting op Melkveebedrijven. IMAG, Wageningen

Hård, M., 1994. Technology as practice: local and global closure processes in dieselengine design. Social Studies of Science 24, 549-585.

Jacobson, S., Bergek, A., 2004. Transforming the energy sector: the evolution of technological systems in renewable energy technology. Industrial and Corporate Change 13 (5), 815-849.

Kemp, R., Schot, J., Hoogma, R., 1998. Regime shifts to sustainability through processes of niche formation: the approach of strategic niche management. Technology Analysis and Strategic Management 10, 175-196.

Kolb, D.A., 1984. Experiential Learning: Experience as the Source of Learning and Development. Prentice-Hall, Englewood Cliffs.

Law, J., Callon, M., 1992. The life and death of an aircraft: a network analysis of technical change. In: Bijker, W.E., Law, J. (Eds.), Shaping Technology/ Building Society: Studies in Sociotechnical Change. MIT Press, Cambridge, MA, pp. 21-52.

Leonard-Barton, D., 1988. Implementation as mutual adaptation of technology and organisation. Research Policy 17, 251-267.

Linton, J.D., 2009. De-babelizing the language of innovation. Technovation 29 (11), 729-737.

Lynn, G.S., Morone, J.G., Paulson, A.S., 1996. Marketing and discontinuous innovation: the probe and learn process. California Management Review 38, 8-37.

March, J.G., 1991. Exploration and exploitation in organizational learning. Organization Science 2, 71-87.

Mayr, E., 1963. In: Animal Species and Evolution. Harvard University Press, Cambridge, MA.

Mokyr, J., 1990. In: The Lever of Riches: Technological Creativity and Economic Progress. Oxford University Press, New York.

Nelson, R.R., Winter, S.G., 1982. In: An Evolutionary Theory of Economic Change. Belknap Press, Cambridge, MA.

Oudshoorn, N., Pinch, T. (Eds.), 2003. How Users Matter: The Co-Construction of Users and Technology. MIT Press, Cambridge, MA.

Powell, W., DiMaggio, P. (Eds.), 1991. The New Institutionalism in Organizational Analysis. The University of Chicago Press, Chicago.

Raven, R.P.J.M., 2005. Strategic Niche Management for Biomass. Eindhoven University Press, Eindhoven.

Raven, R.P.J.M., 2006. Towards alternative trajectories: reconfigurations in the Dutch electricity regime. Research Policy 35, 581-595.

Saviotti, P.P., 1996. Technological Evolution. Variety and the Economy. Edward Elgar, Cheltenham, UK.

Schot, J.W., Geels, F.W., 2007. Niches in evolutionary theories of technical change: a critical survey of the literature. Journal of Evolutionary Economics 17, $605-622$.

Schot, J.W., Geels, F.W., 2008. Strategic niche management: theory, findings, and research agenda. Technology Analysis \& Strategic Management 20 (5), 537554

Scott, W.R., 1995. In: Institutions and Organizations. Sage publications, Thousand Oaks, CA.

Seadi, T.A., 2000. Danish Centralised Biogas Plants. University of Southern Denmark, Esbjerg.

Simon, H.A., 1957. In: Administrative Behavior: A Study of Decision-Making Processes in Administrative Organization. MacMillan, New York.

Thomke, S.,H., 2003. In: Experimentation Matters: Unlocking the Potential of New Technologies for Innovation. Harvard Business School Press, Boston.

Van den Broek, R.C.A., Oudhuis, A.B.J., Van der Hem, A.N., Hemmes, K., Wasser, R., 2002. Evaluatie Nederlandse Biomassa Conversie Installatie. Novem, Utrecht.

Van Lente, H., 1993. Promising Technology: The Dynamics of Expectations in Technological Development. Eburon, Delft.

Van Velsen, A.F.M., 1986. Biogas uit Mest: Hoe Verder na 1986. Haskoning, Nijmegen.

Verheul, H., Vergragt, P.J., 1995. Social experiments in the development of environmental technology: a bottom-up perspective. Technology Analysis \& Strategic Management 7, 315-326.

Watanabe, C., Lei, S., Ouchi, N., 2009. Fusing indigenous technology development and market learning for greater functionality development-an empirical analysis of the growth trajectory of Canon printers. Technovation 29 (4), 265283.

Weick, K.E., 1979. The Social Psychology of Organizing. Addison-Wesley, Reading, MA

Werkgroep Bedrijfsopzetten Biogasinstallaties, A., 1982. Biogas op Veebedrijven. Toepassingsmogelijkheden en Perspectieven. IMAG, Wageningen. 